\title{
Bone Marrow Transplantation Confers Modest Benefits in Mouse Models of Huntington's Disease
}

\author{
Wanda Kwan, ${ }^{1,2}$ Anna Magnusson, ${ }^{7}$ Austin Chou, ${ }^{3}$ Anthony Adame, ${ }^{8}$ Monica J. Carson, ${ }^{9}$ Shinichi Kohsaka, ${ }^{10}$ \\ Eliezer Masliah, ${ }^{8}$ Thomas Möller, ${ }^{11}$ Richard Ransohoff, ${ }^{12}$ Sarah J. Tabrizi, ${ }^{13}$ Maria Björkqvist, ${ }^{7}$ \\ and Paul J. Muchowski 1,2,3,4,5,6 \\ ${ }^{1}$ Biomedical Sciences Program, ${ }^{2}$ Gladstone Institute of Neurological Disease, ${ }^{3}$ Neuroscience Program, ${ }^{4}$ The Taube-Koret Center for Huntington's Disease \\ Research, and Departments of ${ }^{5}$ Biochemistry and Biophysics and ${ }^{6}$ Neurology, University of California, San Francisco, San Francisco, California 94158 , \\ ${ }^{7}$ Brain Disease Biomarker Unit, Department of Experimental Medical Sciences, Wallenberg Neuroscience Center, Lund University, S-221 84 Lund, Sweden, \\ ${ }^{8}$ Department of Neurosciences, University of California, San Diego, La Jolla, California, 92093, ${ }^{9}$ Division of Biomedical Sciences, Center for Glial-Neuronal \\ Interactions, University of California, Riverside, California 92521, ${ }^{10}$ Department of Neurochemistry, National Institute of Neuroscience, Kodaira, Tokyo \\ 187-8502, Japan, ${ }^{11}$ Department of Neurology, School of Medicine, University of Washington, Seattle, Washington 98195, ${ }^{12}$ Neuroinflammation Research \\ Center, Department of Neurosciences, Lerner Research Institute, Cleveland Clinic, Cleveland, Ohio 44195, and ${ }^{13}$ Department of Neurodegenerative Disease, \\ UCL Institute of Neurology, London WC1N 3BG, United Kingdom
}

Huntington's disease (HD) is caused by an expanded polyglutamine tract in the protein huntingtin (htt). Although HD has historically been viewed as a brain-specific disease, $h t t$ is expressed ubiquitously, and recent studies indicate that mutant htt might cause changes to the immune system that could contribute to pathogenesis. Monocytes from HD patients and mouse models are hyperactive in response to stimulation, and increased levels of inflammatory cytokines and chemokines are found in pre-manifest patients that correlate with pathogenesis. In this study, wild-type (WT) bone marrow cells were transplanted into two lethally irradiated transgenic mouse models of $\mathrm{HD}$ that ubiquitously express full-length htt (YAC128 and BACHD mice). Bone marrow transplantation partially attenuated hypokinetic and motor deficits in HD mice. Increased levels of synapses in the cortex were found in HD mice that received bone marrow transplants. Importantly, serum levels of interleukin-6, interleukin-10, CXC chemokine ligand 1, and interferon- $\gamma$ were significantly higher in HD than WT mice but were normalized in mice that received a bone marrow transplant. These results suggest that immune cell dysfunction might be an important modifier of pathogenesis in HD.

\section{Introduction}

Huntington's disease (HD) is a fatal neurodegenerative disorder caused by an expanded polyglutamine repeat in huntingtin (htt), a protein that is expressed ubiquitously. Numerous studies have shown that pathology in HD is not restricted to the CNS (Propert, 1980; Björkqvist et al., 2005; Sassone et al., 2009; van der Burg et al., 2009; Hult et al., 2011; Soulet and Cicchetti, 2011).

\footnotetext{
Received Sept. 22, 2011; revised Oct. 31, 2011; accepted Nov. 1, 2011.

Author contributions: W.K., A.C., A.A., M.J.C., E.M., T.M., R.R., S.J.T., M.B., and P.J.M. designed research; W.K., A.M., A.C., A.A., E.M., and M.B. performed research; S.K. contributed unpublished reagents/analytic tools; W.K., A.M., A.C., A.A., M.J.C., E.M., T.M., R.R., S.J.T., M.B., and P.J.M. analyzed data; W.K., T.M., R.R., S.J.T., M.B., and P.J.M. wrote the paper.

This study was supported by the J. David Gladstone Institutes, The Taube-Koret Center for Huntington's Disease Research, and a Postgraduate Scholarship from Natural Sciences and Engineering Research Council, Canada. We thank Dr. Blair Leavitt (University of British Columbia, Vancouver, BC, Canada) for the YAC128 mice, Dr. William Yang (University of California, San Diego, La Jolla, CA) for the BACHD mice, and Dr. Eric Verdin (Gladstone Institute of Immunology and Virology, San Francisco, (A) for providing the $\beta$-actin GFP mice. We also thank G. Howard for editorial assistance. Data for this study were partially acquired at the University of California, San Francisco Nikon Imaging Center. Behavioral data were obtained with the help of the Gladstone Institutes' Behavioral Core (supported by National Institutes of Health Grant P30NS065780).

Correspondence should be addressed to Paul J. Muchowski, Gladstone Institute of Neurological Disease, 1650 Owens Street, San Francisco, CA 94158. E-mail: pmuchowski@gladstone.ucsf.edu.

DOI:10.1523/JNEUROSCI.4846-11.2012

Copyright $\odot 2012$ the authors $\quad 0270-6474 / 12 / 320133-10 \$ 15.00 / 0$
}

Notably, the immune system in HD is abnormal. Immune markers (Leblhuber et al., 1998), proinflammatory cytokines (Björkqvist et al., 2008), and chemokines (Wild et al., 2011) are elevated in HD patients' blood in the prodromal stage. Peripheral blood monocytes (PBMCs) isolated from HD patients produce increased levels of proinflammatory cytokines after stimulation (Björkqvist et al., 2008). These cells also show a profound impairment in migration to an immune stimulus, and similar results are observed for macrophage migration in vivo in mouse models of HD (Kwan W, Traeger U, Davalos D, Andre R, Chou A, Miller A, Möller T, Stella N, Akassaglou K, Tabrizi SJ, Muchowski PJ, unpublished observations). The kynurenine/tryptophan ratio, an indicator of ongoing inflammation, is elevated in the serum of HD patients (Stoy et al., 2005). Immediate early response 3, a gene that functions to protect cells from TNF- $\alpha$-induced apoptosis, is upregulated in HD blood (Runne et al., 2007). Markers of mitochondrial dysfunction and/or apoptosis are increased in blood cells from HD patients (Almeida et al., 2008). These studies provide strong evidence that the peripheral immune system is abnormal in HD.

Microglia, which function as immune cells in the brain, are also abnormal in HD. Reactive and dystrophic microglia occur in vulnerable brains regions of HD patients and mouse models in a manner that predicts disease manifestation and correlates with 
disease progression (Sapp et al., 2001; Simmons et al., 2007; Tai et al., 2007; Politis et al., 2011). Microglia that express mutant htt have increased levels of proinflammatory cytokines (Björkqvist et al., 2008) and kynurenine metabolites (Giorgini et al., 2008) and have impaired process extension and retraction and responses to injury (Kwan W, Traeger U, Davalos D, Andre R, Chou A, Miller A, Möller T, Stella N, Akassaglou K, Tabrizi SJ, Muchowski PJ, unpublished observations).

Several studies have used lethal irradiation and bone marrow transplants (BMTs) in mouse models of neurodegeneration to experimentally replace the peripheral immune system and allow bone-marrow-derived cells (BMDCs) to enter the brain. In a mouse model of familial amyotrophic lateral sclerosis, transplantation with wild-type (WT) bone marrow (BM) delays the onset and progression of disease (Beers et al., 2006). In Alzheimer's disease (AD) mouse models, BMDCs enter the brain parenchyma and decrease amyloid plaques (Simard et al., 2006). Although recent studies indicate that the recruitment of BMDCs to the brain is likely a result of the irradiation procedure (Ajami et al., 2007; Mildner et al., 2007; Ransohoff, 2007), it is clear that BMT has shown beneficial effects in multiple independent mouse models of neurodegeneration.

Here we determined whether BMTs could modify disease phenotypes in mouse models of HD. We find that BMTs with WT cells conferred modest behavioral benefits, improved brain pathology, and normalized peripheral cytokine levels. These results indicate that mutant htt causes cell-autonomous effects in immune cells that may contribute to pathogenesis in HD.

\section{Materials and Methods}

Animals and breeding strategy. All experiments and procedures involving mice were approved by the Institutional Animal Care and Use Committee of the University of California, San Francisco. Mice were maintained and bred in accordance with National Institutes of Health guidelines. YAC128 founder mice (FVB/NJ background) were kindly provided by Dr. Blair Leavitt (University of British Columbia, Vancouver, BC, Canada). These mice were crossed once with C57BL/6 mice (The Jackson Laboratory) to generate F1 mixed background mice. Transgenic Iba1eGFP mice (Hirasawa et al., 2005) were crossed also once with FVB/NJ mice to generate $\mathrm{F} 1$ mixed background mice for donors to YAC128 mice F1 mixed background. BACHD founder mice (FVB/NJ background) were kindly provided by Dr. William Yang (University of California, San Diego, La Jolla, CA). These mice were bred with FVB/NJ mice (The Jackson Laboratory). To generate donor mice for BMTs in BACHD mice, WT or BACHD mice were bred with $\beta$-actin GFP (The Jackson Laboratory). For all experiments described in this study, mice of either sex were used.

BMT. BM cells were harvested as described previously (Byram et al., 2004). Briefly, cells were harvested from femurs and tibias from donor animals, resuspended, and injected retro-orbitally into lethally irradiated mice (600 rads $\times 2,3 \mathrm{~h}$ apart). In the YAC128 study, Ibal-eGFP mice served as donors. Recipient mice were irradiated and transplanted at $\sim 4$ weeks of age. Four experimental groups were included in the study: WT mice transplanted with WT BM (WT BM $\rightarrow$ WT, $n=11$ ), YAC128 mice transplanted with WT BM (WT BM $\rightarrow$ YAC128, $n=19$ ), nontransplanted WT $(n=22)$, and non-transplanted YAC128 ( $n=19)$ (Fig. $1 A)$. In the BACHD study, $\beta$-actin GFP transgenic mice served as donors. Recipient mice were lethally irradiated and transplanted at 8 weeks of age. Six experimental groups were included in the study: WT mice transplanted with WT BM (WT BM $\rightarrow$ WT, $n=19)$, BACHD mice transplanted with WT BM (WT BM $\rightarrow$ BACHD, $n=20$ ), WT mice transplanted with BACHD BM (BAC BM $\rightarrow$ WT, $n=16$ ), BACHD mice transplanted with BACHD BM (BAC BM $\rightarrow$ BACHD, $n=23$ ), nontransplanted WT mice $(n=21)$, and non-transplanted BACHD mice $(n=21)$ (Fig. $1 B)$. Blood samples were collected, and the efficiency of BMT was quantified by fluorescent-activated cell sorting (FACS) us- ing anti-CD11b-PE (1:4000; eBioscience) and GFP expression as readouts (FACS-Calibur; BD Biosciences). For both the YAC128 and BACHD studies, lethal irradiation was confirmed in three to five irradiated mice without BMT. These mice died within 5-14 d after irradiation procedure.

Isolation of mononuclear cells in adult mouse brains. Mice were perfused with $0.9 \%$ saline. Brains were dissected and homogenized, and mononuclear cells were separated in a discontinuous 30/70 Percoll gradient (Cardona et al., 2006). Isolated cells were stained with anti-CD45-PerCP (1:100; BD Biosciences Pharmingen). FACS plots were analyzed by gating for $\mathrm{CD}_{4} 5^{+}$populations and determining GFP expression among CD45-dim and CD45-high regions.

Open-field activity assays. Spontaneous locomotor activity in an openfield arena was measured in an automated Flex-Field/Open Field Photobeam Activity System (San Diego Instruments). Before testing, mice were transferred to the testing room and acclimated for at least $1 \mathrm{~h}$. Mice were tested in a clear plastic chamber $(41 \times 41 \times 30 \mathrm{~cm})$ for $10-30 \mathrm{~min}$, with two $16 \times 16$ photobeam arrays detecting horizontal and vertical movements. The apparatus was cleaned with $70 \%$ alcohol after testing of each mouse. Total movements in the open field were recorded for additional data analysis.

Rotarod and balance-beam traversal assays. Mice were trained on the rotarod (San Diego Instruments) at $16 \mathrm{rpm}$ for $5 \mathrm{~min}$. Mice were then tested for three consecutive accelerating trials of $5 \mathrm{~min}$ each with a speed at 4-40 rpm and an intertrial interval of $60 \mathrm{~min}$. The sequence was repeated for $3 \mathrm{~d}$. Values were averaged across all trials. A balance-beam traversal assay was performed as described previously (Heng et al., 2007). Briefly, mice were trained for three trials on the balance beam and then evaluated for latency to cross the beam for three trials. The intertrial interval was $60 \mathrm{~min}$.

Neuropathology. YAC128 mice were killed at 12 and 18 months; BACHD mice were killed at 12-14 months. Mice were deeply anesthetized with Avertin (tribromoethanol, $250 \mathrm{mg} / \mathrm{kg}$ ) and transcardially perfused with $0.9 \%$ saline. One hemibrain was drop fixed in $4 \%$ paraformaldehyde for $48 \mathrm{~h}$ and stored at $2 \%$ paraformaldehyde until use. The other hemibrain was snap frozen at $-70^{\circ} \mathrm{C}$. Coronal sections $(30$ $\mu \mathrm{m}$ ) were prepared using a cryostat sliding microtome (Leica Microsystems). Sagittal sections $(50 \mu \mathrm{m})$ were prepared using a Vibratome-3000 (Leica Microsystems). Sections were labeled with anti-synaptophysin (1 $\mu \mathrm{g} / \mathrm{ml}$; Roche Diagnostics) and FITC-conjugated horse anti-mouse IgG (1:500; Vector Laboratories) and imaged by confocal microscopy (Nikon C1si Spectral Confocal). Microglial immunoreactivity was quantified by immunostaining of sections with a rabbit monoclonal antibody against Ibal (1:1000; Wako), biotinylated secondary antibody, avidin coupled to horseradish peroxidase and reacted with DAB. BM-derived brain macrophages/microglia were quantified by colabeling sections with anti-Iba1 (secondary with anti-rabbit Alexa Fluor 549; Jackson ImmunoResearch) and anti-GFP (secondary with anti-mouse FITC; Vector Laboratories). For all immunohistochemistry analyses, at least three fields of views were imaged randomly, and the percentage of immunoreactivity was evaluated by MetaMorph software (Molecular Devices). To compare immunoreactivities of antibody staining between each sample, we selected similar sections based on the neuroanatomy of each section, such as using the structure of the striatum and the hippocampus as guidelines. We imaged each section with similar microscopy acquisition settings to ensure comparable immunoreactivity levels for the analyses. All studies were performed with the experimenter blinded to the genotype and treatment group.

Serum cytokine analysis. Blood samples were obtained from animals at 6, 9, and 12 months after behavioral testing. Serum cytokine levels were quantified using Meso Scale Discovery (MSD; Meso Scale Diagnostics) electrochemiluminescence assays using a modification of the protocol of the manufacturer. Twenty microliters were used as the sample volume, and a 10-point standard curve was used, ranging from 2500 to $0 \mathrm{pg} / \mathrm{ml}$. The sample and calibrator were incubated on the MSD plate for $3 \mathrm{~h}$ (instead of $2 \mathrm{~h}$ ), followed by a wash (as per the recommendations of the manufacturer). The MSD plate was then incubated with detection antibody solution for $3 \mathrm{~h}$ (instead of $2 \mathrm{~h}$ ) before wash and read as per the recommendation of the manufacturer. Results were analyzed on a 
A

Non-transplanted
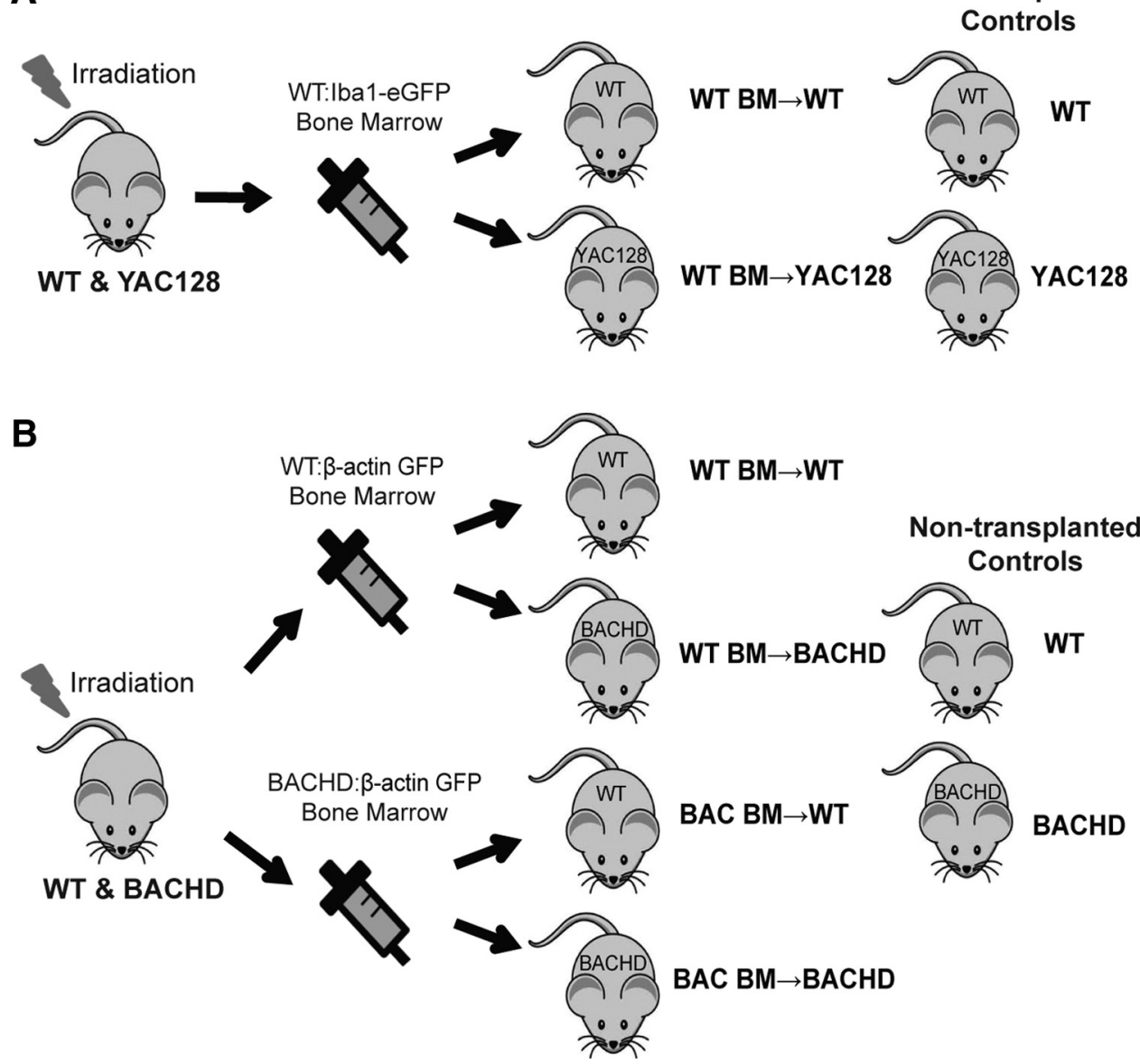

Figure 1. Generation of BM chimeras in YAC128 and BACHD full-length transgenic htt mouse models. $A$, YAC128 mice and WT littermates were lethally irradiated at $\sim 4$ weeks of age and transplanted with BM from transgenic Iba1- eGFP mice. B, BACHD mice and WT littermates were lethally irradiated at 2 months of age and transplanted with BM from $\beta$-actin GFP mice or BACHD; $\beta$-actin GFP mice. Non-transplanted WT and YAC128/BACHD mice were also tested in these studies.

SECTOR 6000 instrument (Meso Scale Diagnostics). All studies were performed with the experimenter blinded to the genotype and treatment group. Serum cytokines were normalized to the non-transplanted WT or chimeric WT control samples, because irradiation and BMT were found to elevate some peripheral cytokines at early time points after transplantation.

Statistics. All data are expressed as the mean \pm SEM. For each outcome measure, a one-way ANOVA with the Bonferroni's post hoc test was performed to determine levels of significance between experimental groups at each time point. In cases in which the graphs included multiple time points, a two-way ANOVA with the Bonferroni's post hoc test was performed because there were two variables in the analyses. Statistical analyses were performed using the GraphPad Prism Software.

\section{Results}

BMT is well tolerated and leads to efficient reconstitution of host-derived cells in HD mouse models

BMT were performed after lethal irradiation in 4- and 8-weekold YAC128 and BACHD mice, respectively (Fig. 1). Iba1-eGFP mice were used as donors for YAC128 mice and WT littermates. Either $\beta$-actin GFP transgenic mice or BACHD; $\beta$-actin GFP mice were used as donors for BACHD mice and WT littermates. The efficiency of reconstitution of BMDCs was determined in the blood of chimeric WT and BACHD mice using FACS 12-14 weeks after transplantation by gating for GFP-expressing $\left(\mathrm{GFP}^{+}\right)$ and $\mathrm{CD} 11 \mathrm{~b}^{+}$cells. The percentage of $\mathrm{GFP}^{+} / \mathrm{CD} 11 \mathrm{~b}^{+}$cells in the blood of chimeric mice was similar to that found in $\beta$-actin GFP donor mice, indicating that the BMT procedure led to an efficient reconstitution of donor-derived cells in WT and BACHD mice (Fig. 2A-C). Similar results were obtained in studies with YAC128 mice (data not shown).

We next used immunohistochemistry to determine whether BMDCs were found in the brains of chimeric mice. At 12-13 months of age, brain sections from BM chimeras were labeled with antibodies against the microglia/macrophage marker Ibal and GFP to evaluate their colocalization. As expected, in tissue sections from the cortex of transgenic Ibal GFP control mice, the majority of cells that expressed GFP were positive for Iba1 (Fig. $2 D$, top row). GFP ${ }^{+} / \mathrm{Ibal}^{+}$cells were also detected in the cortex of chimeric WT (data not shown) and YAC128 mice brains (Fig. $2 D$, middle) but not in brain sections from mice that did not receive a transplant (Fig. $2 D$, bottom). Similar results were obtained in BACHD mice (data not shown). We observed no significant effect of genotype (i.e., no significant effect of the $\mathrm{BACHD}$ transgene) on the levels of $\mathrm{GFP}^{+} / \mathrm{Ibal}^{+}$cells in the cortex of chimeric mice (Fig. 2 E). However, a significant increase in $\mathrm{GFP}+/ \mathrm{Ibal}^{+}$cells in the striatum of BACHD mice that received BACHD BM was observed relative to other genotypes (Fig. $2 F)$. As determined by FACS, GFP-expressing cells in the brains of chimeric mice were comprised of CD45-dim $(\sim 74-81 \%)$ and CD 45 -high ( $\sim 19-26 \%)$ populations (Fig. $2 G, H)$, characteristic of parenchymal microglia and infiltrating macro- 
A

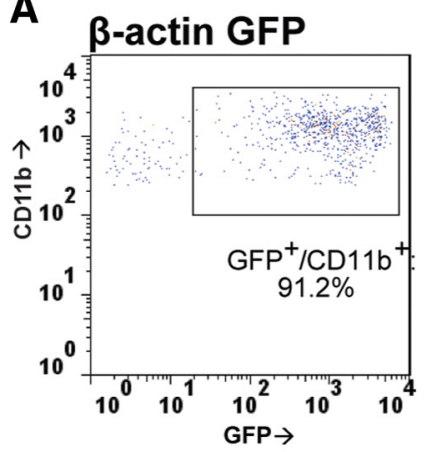

D

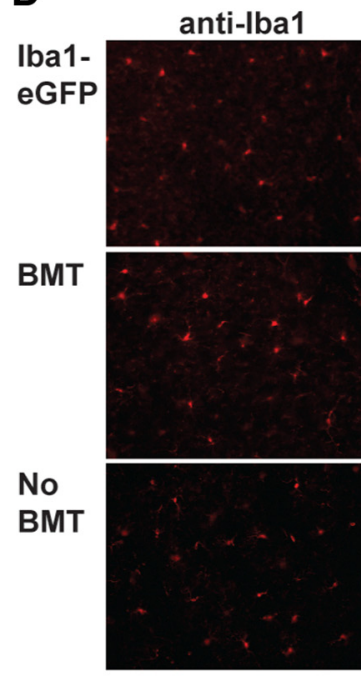

G No BMT

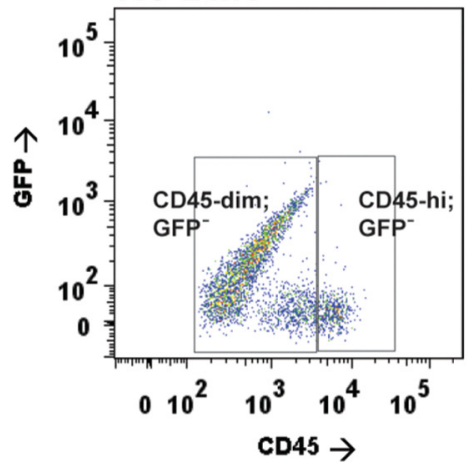

B BMT

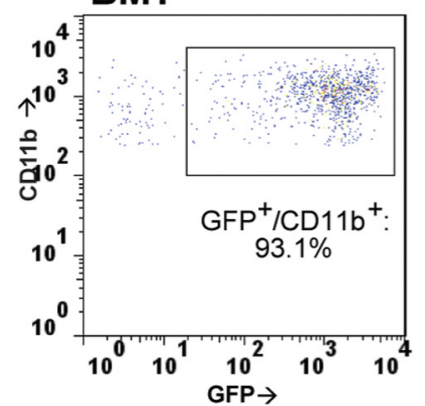

C

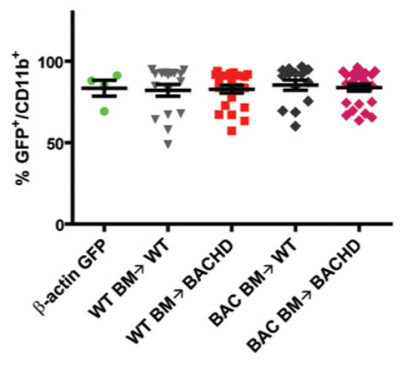

E

E cortex

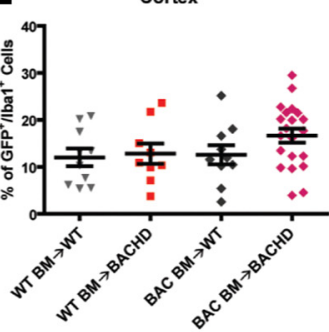

F

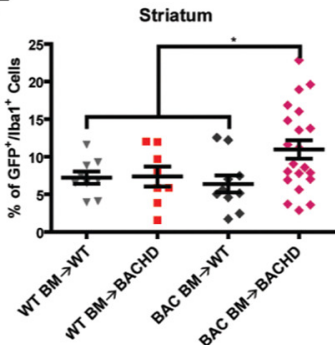

H BMT

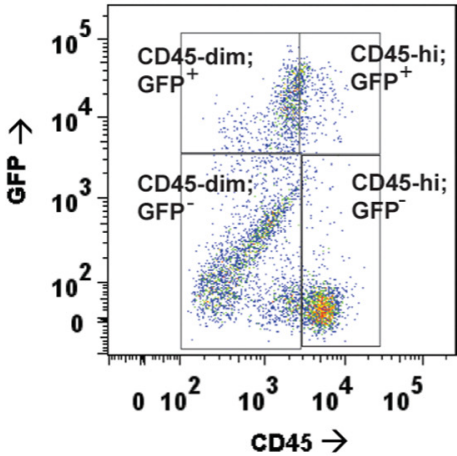

Figure 2. GFP ${ }^{+}$monocytes and BM-derived microglia/macrophages are detected in blood and brains of BM chimeras. $A, B$, Representative FACS data demonstrating that $B M$ chimeras of $B A C H D$ mice had similar levels of GFP ${ }^{+} / \mathrm{CD}_{11 \mathrm{~b}}{ }^{+}$cells in blood as $\beta$-actin GFP transgenic mice $12-14$ weeks after BMT. C, Summary of GFP ${ }^{+} / \mathrm{CD}_{11 \mathrm{~b}}{ }^{+}$cells in blood from $\beta$-actin GFP transgenic mice, WT mice receiving normal $B M(W T B M \rightarrow W T)$, BACHD mice receiving normal $B M(W T B M \rightarrow B A C H D)$, WT mice receiving BACHD BM (BAC BM $\rightarrow$ WT), and BACHD mice receiving BACHD BM (BAC $B M \rightarrow B A C H D)$. D, Representative images from the cortex of perfused brains from lba1-eGFP mice (top), BM chimeras (middle), and non-transplanted mice (bottom) at 12 months, using anti-lba1 and anti-GFP antibodies. $E, F$, Percentage of GFP ${ }^{+} / \mathrm{lba} 1^{+}$cells in experimental cohorts of BM chimeras of WT and BACHD mice. The percentage of GFP ${ }^{+} / \mathrm{lba} 1^{+}$microglia/brain macrophages was not significantly differently in cortex $(\boldsymbol{E})$ but was higher in BAC BM $\rightarrow$ BACHD group in striatum $(\boldsymbol{F})$. Values are mean \pm SEM $(p<0.05$, one-way ANOVA). $\boldsymbol{G}, \boldsymbol{H}$, Representative FACS data demonstrating that GFP ${ }^{+}$cells from the brains of BMT mice are composed of CD45-dim $(\sim 74-81 \%)$ and CD45-high $(\sim 19-26 \%)$ populations, characteristic of parenchymal microglia and infiltrating macrophages, respectively.

phages, respectively. Overall, our results indicate that BMT after lethal irradiation is well tolerated and leads to a significant recruitment of BMDCs into the blood and brains of two independent mouse models of HD.

BMT confers modest protection against behavioral deficits in mouse models of HD

We first evaluated the effects of BMT in the YAC128 transgenic mouse model of HD that expresses full-length htt and displays be- havioral and neuropathological deficits that may resemble those found in HD patients (Hodgson et al., 1999; Slow et al., 2003; Menalled et al., 2009). BM from Iba1-eGFP transgenic mice was transplanted into lethally irradiated $\sim 4$-week-old WT and YAC128 mice. As reported (Slow et al., 2003), nontransplanted YAC128 mice were significantly $(p<0.001)$ heavier than WT littermate controls. Although mice that received transplants weighed significantly $(p<0.001)$ less than non-transplanted littermate controls, there was no effect of 

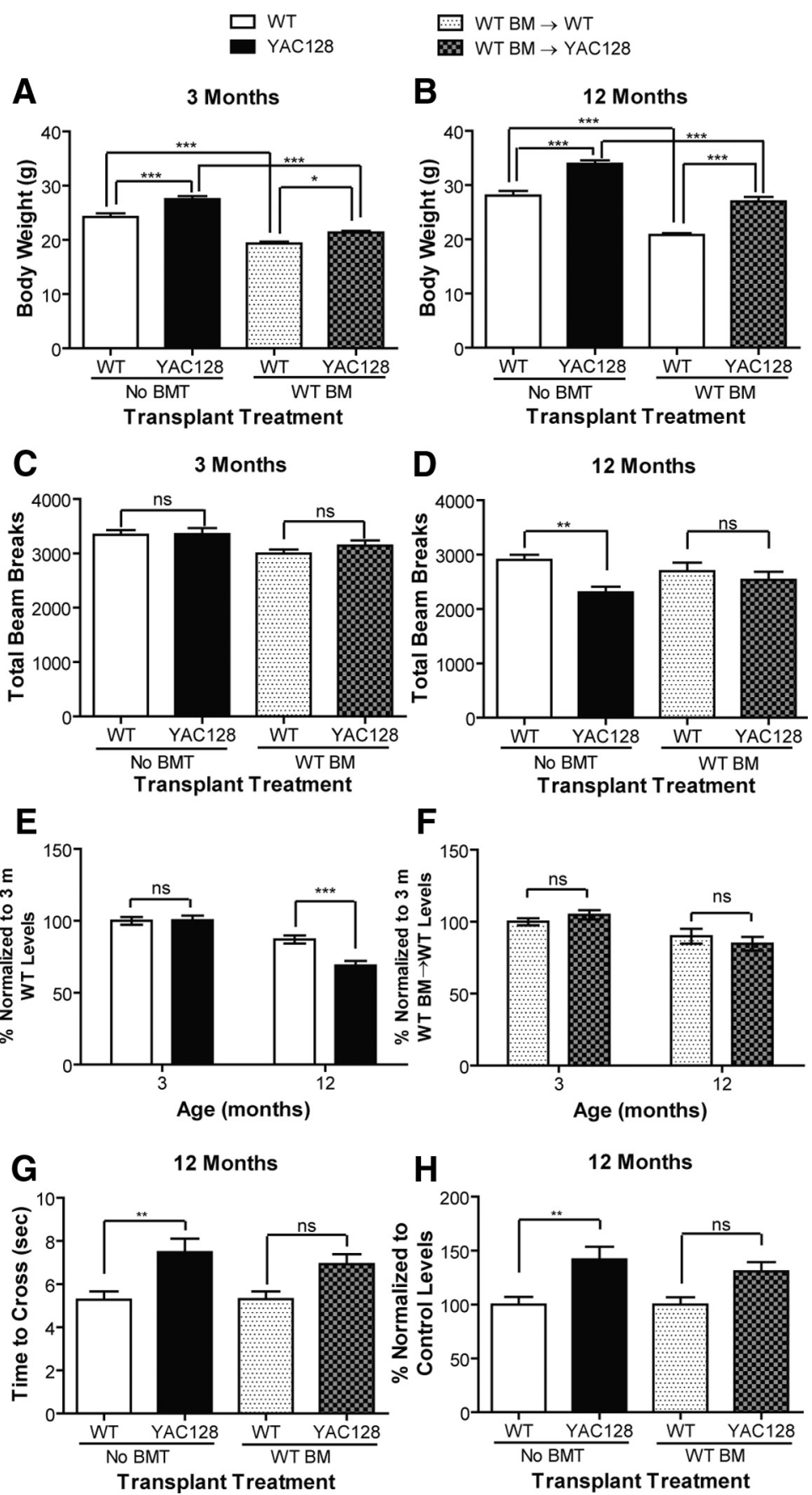

Figure 3. BMT in YAC128 mice confers modest behavioral benefits. $\boldsymbol{A}, \boldsymbol{B}$, Non-transplanted YAC128 mice were significantly $(p<0.001)$ heavier than WT littermate controls at 3 and 12 months. Similarly, transplanted YAC128 mice were significantly $(p<$ 0.001 ) heavier than WT transplanted mice. Transplanted WT and YAC128 mice weighed less than the non-transplanted controls $(p<0.001)$. C, $\boldsymbol{D}$, At 3 months, there was no effect of genotype on general activity using an open-field apparatus. However, at 12 months, non-transplanted YAC128 mice displayed hypokinetic activity $(p<0.01)$, which was not observed in YAC128 mice that received a WT BMT. Values are mean \pm SEM ( ${ }^{* *} p<0.01$, one-way ANOVA, Bonferroni's post hoc test). $\boldsymbol{E}, \boldsymbol{F}, 0$ pen-field activity is normalized to WT and WT BM $\rightarrow$ WT controls, respectively, at 3 months. Values are mean \pm SEM $\left({ }^{* * *} p<0.001\right.$, two-way ANOVA Bonferroni's post hoc test). G, Balance-beam performance was worse in non-transplanted YAC128 mice compared with WT littermates $(p<0.01)$ at 12 months; however, chimeric YAC128 mice were not significantly different from chimeric WT littermates. $\boldsymbol{H}$, Balance-beam activity is normalized to WT and WT BM $\rightarrow$ WT controls, respectively. Values are mean \pm SEM $\left({ }^{* *} p<0.01\right.$, one-way ANOVA, Bonferroni's post hoc test).

genotype on body weight in chimeric WT and YAC128 mice (Fig. $3 A, B)$.

We next determined the effects of BMT on hypokinetic deficits in YAC128 mice using an open-field apparatus. As described previously (Slow et al., 2003), YAC128 mice that did not receive a transplant showed a significant $(p<0.01)$ decline in total open-field activity at 12 months of age. In contrast, WT and YAC128 mice that received a WT BMT were not significantly different (Fig. 3C-F).

We also quantified the effects of BMT on motor performance in YAC128 mice, as measured in rotarod and balance-beam traversal assays. Although YAC128 mice showed the typical (Slow et al., 2003) rotarod deficit at 12 months of age $(p<$ $0.0001)$, this deficit was not rescued in mice that received a BMT (data not shown). In contrast, although YAC128 mice performed worse than WT littermates in a balance-beam traversal assay, chimeric YAC128 mice were not significantly different from WT littermates that received a transplant (Fig. $3 G, H$ ).

We further examined the effects of BMT in BACHD mice, which express fulllength htt but may have more robust neuropathological and behavioral deficits than YAC128 mice (Menalled et al., 2009). BM from $\beta$-actin GFP transgenic mice was transplanted into lethally irradiated 8-week-old WT and BACHD mice. Similar to YAC128 mice (Fig. 3A), BACHD mice were significantly $(p<$ 0.001) heavier than WT littermates, and all mice that received a BMT weighed significantly less than those that did not (Fig. $4 A, B)$. Moreover, in transplanted mice, there was no significant effect of genotype on body weight.

We next evaluated the effects of BMT on hypokinetic deficits in BACHD mice using an open-field apparatus. As described previously (Gray et al., 2008), BACHD mice that did not receive a transplant showed significant deficits in total open-field activity at 12 , but not 6 , months of age (Fig. 4C-E). In contrast, $\mathrm{WT}$ and BACHD mice that received WT $\mathrm{BM}$ were not significantly different at 12 months of age (Fig. $4 D, F$ ). BACHD mice that received $\mathrm{BACHD} \mathrm{BM}$ were also not significantly different from BACHD mice that received $\mathrm{WT} B M$, although they are significantly different from WT mice that received WT BM (Fig. $4 F$ ).

We next evaluated the effects of BMT on motor performance in BACHD mice, as measured by rotarod analysis. Although BACHD mice showed significant rotarod deficits at 6 and 12 months of age, as described previously (Gray et al., 2008), BMT of WT cells did not rescue these deficits (data not shown). We also evaluated the effects of BMT in the balance-beam traversal assay. Although BACHD mice were slower than nontransplanted WT littermates at 6 months of age, BACHD mice 


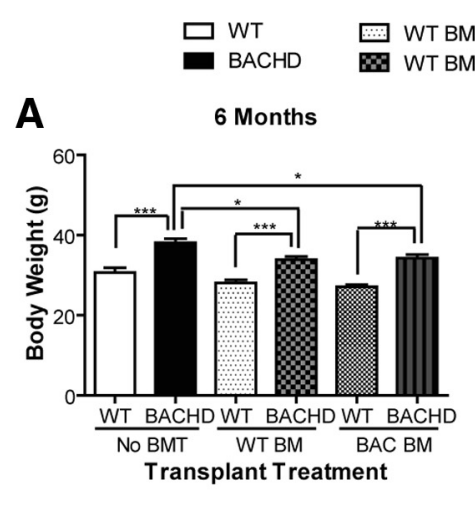

C

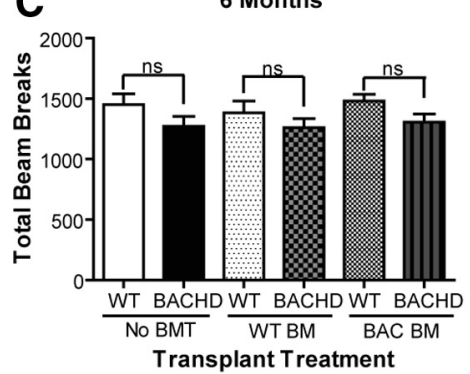

E

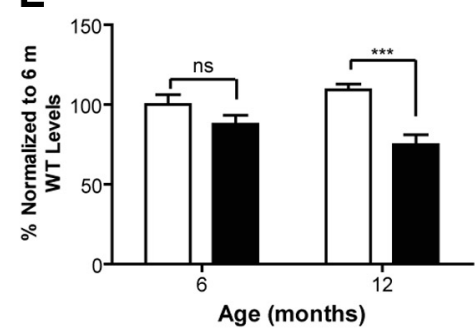

G
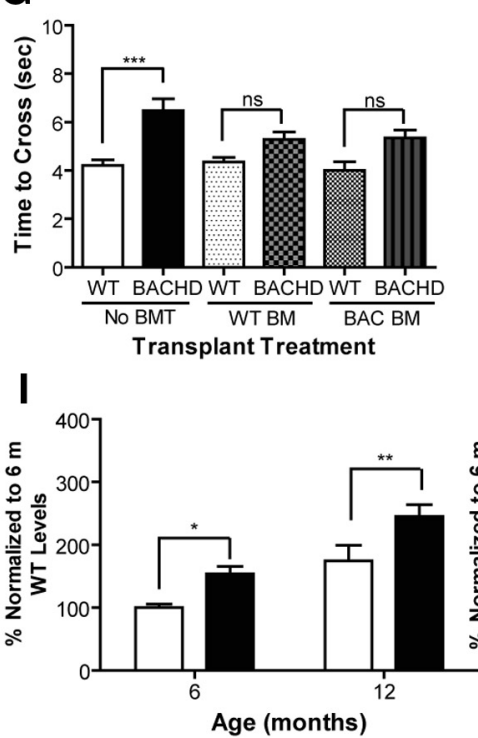

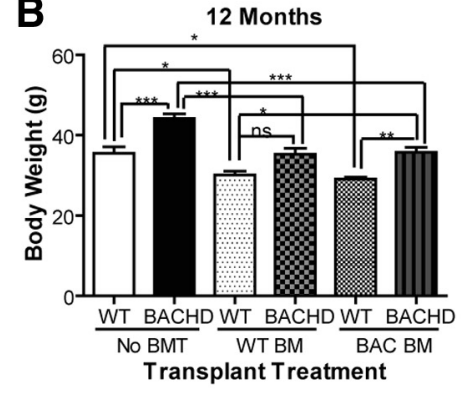

D

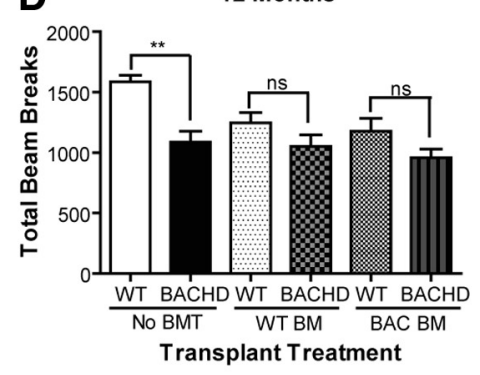

$\mathbf{F}$

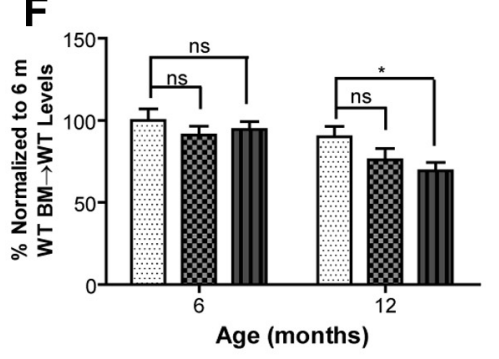

H
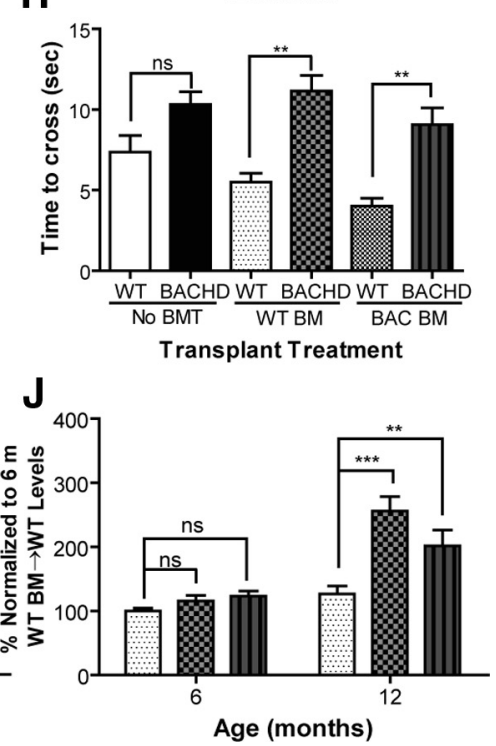

Figure 4. BMT in BACHD mice confers modest behavioral benefits. $\boldsymbol{A}, \boldsymbol{B}$, At 6 and 12 months, non-transplanted BACHD mice were heavier than non-transplanted WT mice $(p<0.001)$. BACHD mice that received a WT BMT were heavier than WT mice that received WT BMT at 6 ( $p<0.001$ ) but not 12 months. $C, D$, At 6 months, there was no genotype effect on general activity using an open-field apparatus. However, at 12 months, non-transplanted BACHD mice displayed hypokinetic activity $(p<0.01)$, which was not observed in WT and BACHD mice that received a WT BMT. BACHD mice that received BACHD BMT were also not significantly different from BACHD mice that received a WT BMT. Values are mean \pm SEM $\left({ }^{* *} p<0.01\right.$, one-way ANOVA, Bonferroni's post hoc test). $\boldsymbol{E}, \boldsymbol{F}$, Open-field activity is normalized to WT controls and WT BM $\rightarrow$ WT controls, respectively, at 6 months. Values are mean \pm SEM $\left({ }^{*} p<0.05,{ }^{* * *} p<0.001\right.$, two-way ANOVA, Bonferroni's post hoc test). G, At 6 months, BACHD mice were slower

that received WT $\mathrm{BM}$ were not significantly different from WT mice that received WT BM at this time point (Fig. $4 G, I, J)$. However, at 12 months of age, a significant effect of genotype on balancebeam performance was observed in BACHD mice that received WT BM (Fig. $4 H, J)$. At this time point, BACHD mice that received $\mathrm{WT} B \mathrm{BM}$ and $\mathrm{BACHD}$ mice that received $\mathrm{BACHD} B M$ were not significantly different (Fig. 4H). Overall, our results suggest that BMT confers modest but significant benefits on some, but not all, behavioral deficits that were examined in YAC128 and BACHD mice.

\section{BMT in BACHD mice increases brain levels of synaptophysin}

The loss of striatal neurons in BACHD mice is observed at late stages of disease, after behavioral manifestations are clearly evident (Gray et al., 2008). Because previous studies described the loss of synapses in R6/2 mice (Cepeda et al., 2003; Wacker et al., 2009), which might correlate better with behavioral deficits, we quantified the effects of BMT on synaptophysin levels in BACHD mice after completion of behavioral assays. Similar to R6/2 mice, synaptophysin levels in the cortex of 12-month-old BACHD mice were significantly lower than in WT littermate controls (Fig. 5A). Although BACHD mice that received a WT BMT had a significant increase in synaptophysin levels, a similar increase was also observed in WT mice that received WT BM. Moreover, WT or $\mathrm{BACHD}$ mice that received a BACHD BMT also had increased synaptophysin levels. Similar results were obtained in the striatum of BACHD mice that received BMTs (data not shown). Interestingly, the increase in synaptophysin levels relative to non-transplanted controls was significantly higher for BACHD than WT mice (Fig. 5B). Because synaptophysin levels were not decreased in YAC128 mice relative to littermate controls at 12 months of age (data not shown), we did evaluate the effects of BMT on this outcome measure.

\section{$\longleftarrow$}

than non-transplanted WT littermates in the balance-beam traversal assay. BACHD mice that received a WT BMT were not significantly different from WT mice that received WT BMT at this time point. $\boldsymbol{H}$, The changes induced by BMT did not persist at 12 months of age. Values are mean \pm SEM $\left({ }^{* *} p<0.01\right.$, ${ }^{* * *} p<0.001$, one-way ANOVA, Bonferroni's post hoc test). I, $J$, Balance-beam activity is normalized to WT and WT $\mathrm{BM} \rightarrow$ WT controls at 6 months. Values are mean $\pm \mathrm{SEM}\left({ }^{*} p\right.$ $<0.05,{ }^{* *} p<0.01,{ }^{* * *} p<0.001$, two-way ANOVA, Bonferroni's post hoc test). 


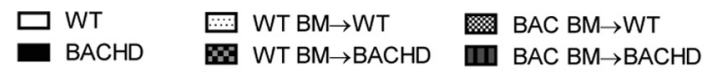

A

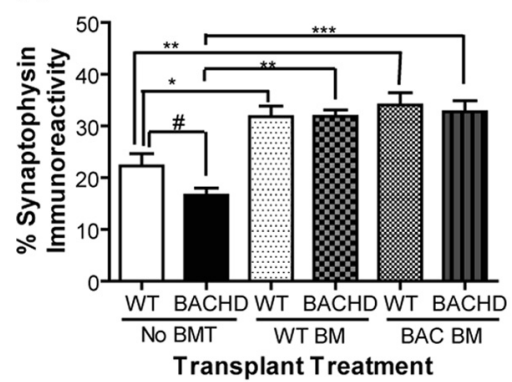

C

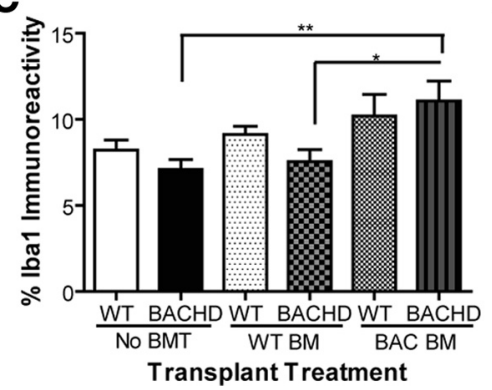

$\mathrm{B}_{\text {s }}$

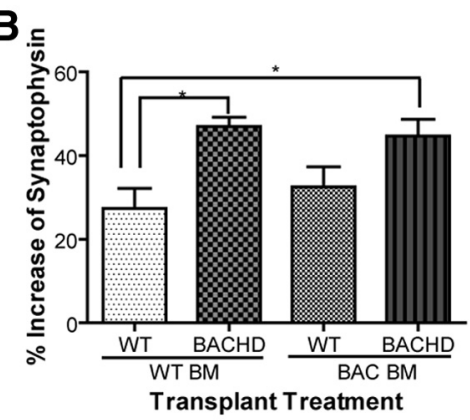

D

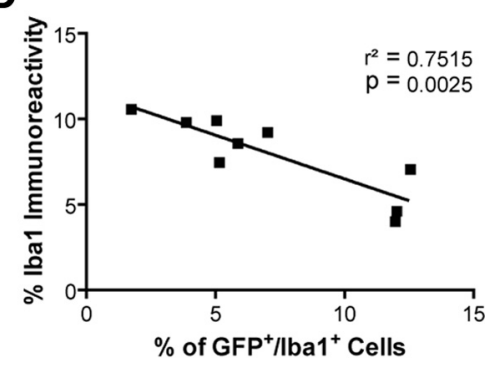

Figure 5. Increased synaptophysin levels are found in WT and BACHD mice that receive lethal irradiation and a BMT. $\boldsymbol{A}$, Synaptophysin levels were decreased in the cortex of 12-month-old BACHD mice compared with WT controls ( ${ }^{\#}<<0.05, t$ test). Synaptophysin levels in transplanted WT and BACHD mice were higher than in the non-transplanted mice. Values are mean \pm SEM $\left({ }^{*} p<0.05,{ }^{* *} p<0.01,{ }^{* * *} p<0.001\right.$, one-way ANOVA, Bonferroni's post hoc test). $\boldsymbol{B}$, The percentage increase of synaptophysin levels, relative to non-transplanted controls, was higher in transplanted BACHD mice than that of the transplanted WT mice. $\boldsymbol{C}$, The levels of Iba1were increased in the striatum of BACHD mice that received a BACHD BMT but not in BACHD mice that received a WT BMT. Values are mean \pm SEM $\left({ }^{*} p<0.05,{ }^{* *} p<0.01\right.$, one-way ANOVA, Bonferroni's post hoc test). $D$, A regression analysis demonstrates that the percentage of BM-derived brain microglia/macrophages ( $\%$ of GFP ${ }^{+} / \mathrm{lba}^{+}{ }^{+}$Cells) correlates inversely to Iba1 immunoreactivity in the striatum of BACHD mice that received a WT BMT ( $p=0.0025$, linear regression analysis).

Previous studies in R6/2 mice and HD brains showed increased staining with an antibody to the protein Iba1 (Simmons et al., 2007; Wacker et al., 2009), consistent with microglial activation and/or proliferation. In contrast, we observed no significant difference in Ibal immunostaining in BACHD mice when compared with WT littermate controls (Fig. 5C). However, BACHD mice that received a BMT from BACHD mice had a significant increase in Iba1 levels when compared with those that received a WT BMT or non-transplanted controls (Fig. 5C). Interestingly, in these mice, Ibal immunoreactivity correlated negatively with the percentage of $\mathrm{Ibal}^{+} / \mathrm{GFP}^{+}$cells, suggesting that infiltrating $\mathrm{GFP}^{+}$cells might potentially decrease the local inflammatory environment in the CNS (Fig. 5D).

\section{BMT normalized cytokine and chemokine changes in YAC128 mice}

Inflammatory cytokines are increased in blood samples from HD patients and in YAC128 mice (Björkqvist et al., 2008). Using a mesoplex assay that measures multiple cytokines and chemokines simultaneously, we found significant increases in interleukin-6 (IL-6), CXCL1 (a functional homolog of IL-8 in mice), interferon- $\gamma$ (IFN- $\gamma$ ), and IL-10 in serum samples of YAC128 mice relative to WT littermate controls (Fig. 6). In contrast, there was little or no significant difference among genotypes for these cytokines and chemokines in mice that received BMTs. Because BACHD mice did not have significant increases in cytokines and chemokines relative to WT littermate controls at 12 months of age (data not shown), we did not evaluate the effects of BMT on this parameter.

\section{Discussion}

HD is widely recognized as a neurodegenerative disorder that is associated with massive loss of medium spiny neurons in the striatum. However, many studies indicate that pathology is also observed in other brain regions and non-neuronal tissues (Sathasivam et al., 1999; Rosas et al., 2003; Björkqvist et al., 2005; Sassone et al., 2009; van der Burg et al., 2009; Hult et al., 2011). A number of studies describe the early and chronic elevation of proinflammatory cytokines (Dalrymple et al., 2007; Björkqvist et al., 2008) and chemokines (Wild et al., 2011) in HD, and these signaling molecules are hypothesized to derive from cell-autonomous effects of mutant htt in monocytes and macrophages. In this study, we tested whether reconstituting the peripheral immune system by performing allogeneic BMT with WT cells in two HD mouse models influenced pathogenesis. We found that this procedure is well tolerated and modestly, but significantly, ameliorated a number of behavioral and pathological deficits and normalized levels of cytokines and chemokines. Although the magnitude of protective effects from BMT in $\mathrm{HD}$ mice are clearly modest, it is worth emphasizing that these benefits occur in the context of mutant htt continuously exerting toxic effects in neurons and other tissues. As such, our results suggest that immune cells may play a disease-modifying role in $\mathrm{HD}$ that might be amenable to therapeutic intervention. Importantly, transplantation of HD BM into WT mice did not cause behavioral or neuropathological deficits (data not shown), reinforcing the hypothesis that mutant htt induced changes in peripheral immune cells contribute to, but do not cause, neurodegeneration.

BMT led to a significant increase in levels of synaptophysin immunostaining in the brains of BACHD mice. To our surprise, synaptophysin levels were increased in all mice that received a transplant after lethal irradiation, even when the $\mathrm{BM}$ was derived from BACHD mice. Increased synaptophysin levels have also been described after lethal irradiation and BMT in mouse models of AD and stroke (Zhang et al., 2006; Ding et al., 2011; Hao et al., 2011). The mechanisms that underlie increased synaptogenesis after BMT are not well understood, but several studies have shown that total body irradiation leads to a breakdown in the blood-brain barrier concomitant with increased levels of cytokines and chemokines, which leads to the infiltration of BMDCs into the brain parenchyma (Ajami et al., 2007; Mildner et al., 2007). We hypothesize that BMDCs that enter the brain are attracted to vulnerable brain regions by local production of chemokines and cytokines and may support synaptogenesis by secreting neurotrophic factors (Zhang et al., 2006; Mildner et al., 2007; Björkqvist et al., 2008). Infiltrating BMDCs might also directly survey and protect synapses in an effort to restrict additional 
damage, as described for parenchymal microglia (Davalos et al., 2005; Wake et al., 2009). Interestingly, although all mice that received transplants had increased levels of synaptophysin, the relative increase of synaptophysin levels was highest for BACHD chimeras that received a WT BMT. Similar observations were found with mouse behaviors. Furthermore, the levels of apparent microglial activation as determined by Ibal immunostaining correlated negatively with levels of infiltrating $\mathrm{Ibal}^{+} / \mathrm{GFP}^{+}$cells in these mice. Because synapse loss may precede frank neuronal loss in HD patients (Cepeda et al., 2003; Tabrizi et al., 2011), we believe that our data showing increased synaptophysin levels after BMT might have important clinical implications.

BMT in YAC128 mice also resulted in the normalization of cytokine and chemokine levels. Levels of IL-6, IL-8, IFN- $\gamma$, and IL-10 are increased in the blood of HD patients and mouse models (Björkqvist et al., 2005; Dalrymple et al., 2007). Confirming previous studies, these cytokines were increased in YAC128 mice, and these changes were largely attenuated in mice that received a BMT from WT mice. It was previously hypothesized that increased levels of cytokines and chemokines that occur in HD patients are attributable to a cell-autonomous effect of mutant htt expression in BMDCs (i.e., monocytes and macrophages), and our data strongly support this hypothesis. Surprisingly, we did not observe any significant changes in levels of cytokines and chemokines in BACHD mice, and this may be attributable in part to the fact that these mice were on a different strain background than the YAC128 mice that were used in this study.

Chronic increased levels of cytokines and chemokines may have deleterious consequences that could ostensibly contribute to pathogenesis in peripheral tissues as well as neurodegeneration in the CNS. For example, IFN- $\gamma$ and IL- 6 are key signaling molecules in the immune system that activate macrophages and the production of other cytokines that mediate fever and the acute phase response and might also contribute to muscle wasting and cachexia that is observed in HD patients. Indeed, in separate studies, depletion of IL- 6 with a monoclonal antibody prevented weight loss in the R6/2 mouse model of HD (Larimore J, Truong J, Bouchard K, Tabrizi SJ, Stella N, Muchowski PJ, unpublished observations). IL-8 is a chemokine produced by macrophages and epithelial cells that binds CXCR1/CXCR2 and is a chemoattractant that induces chemotaxis of neutrophils. Increased levels of this and other chemokines might suggest that diseased tissues in HD patients are sending danger signals to induce an innate
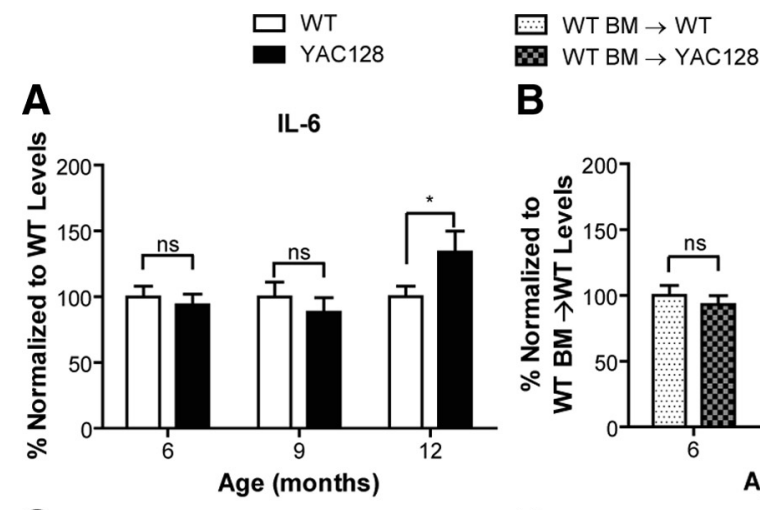

B

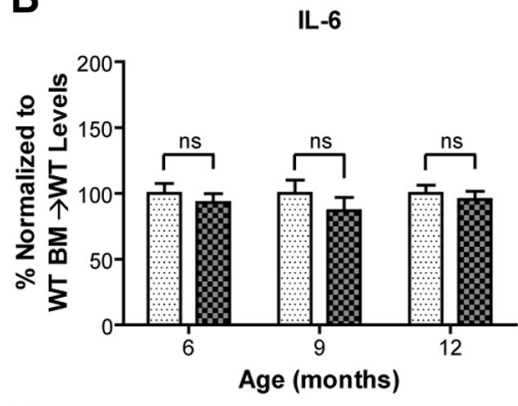

D $\quad$ CXCL1
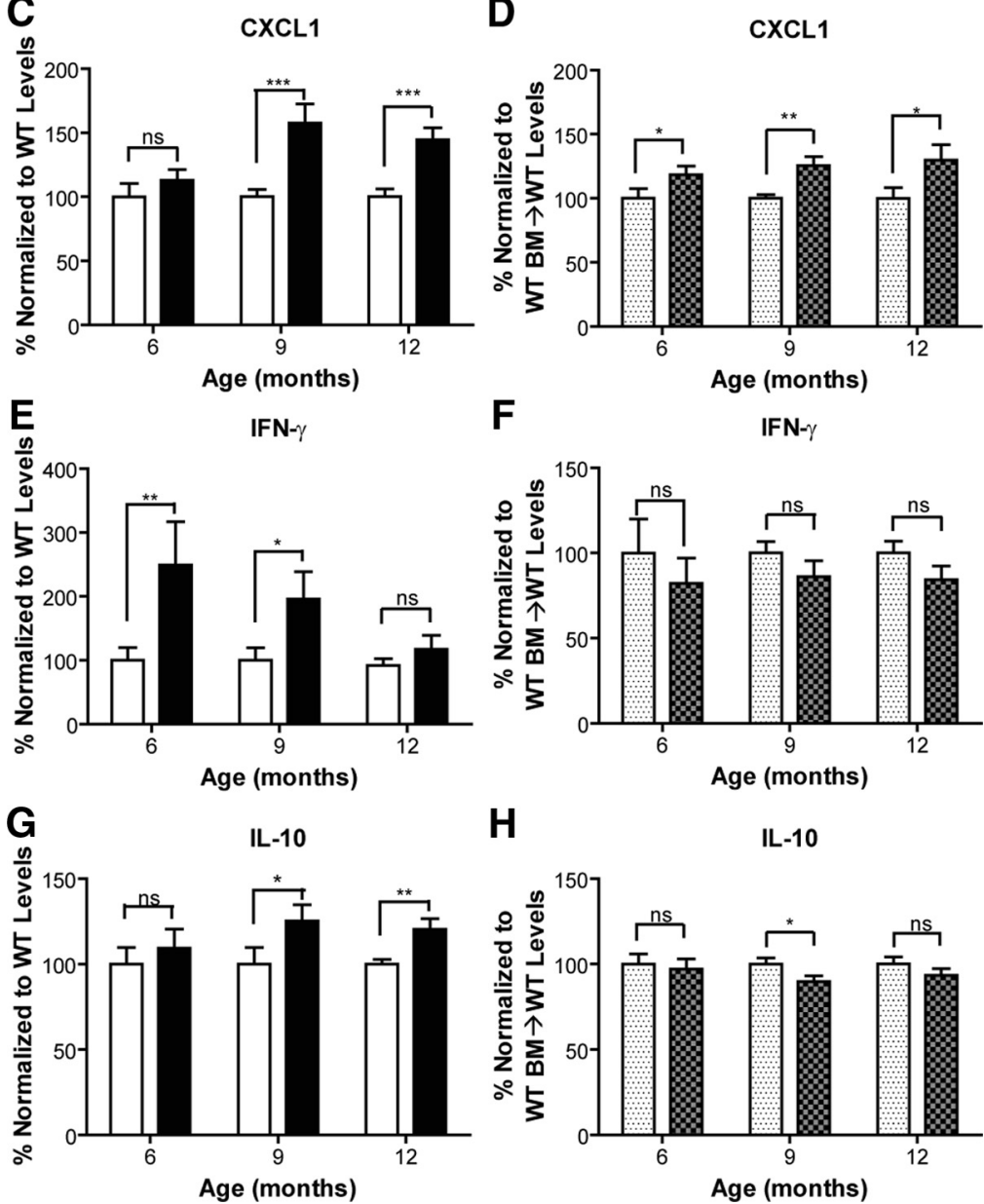

H IL-10

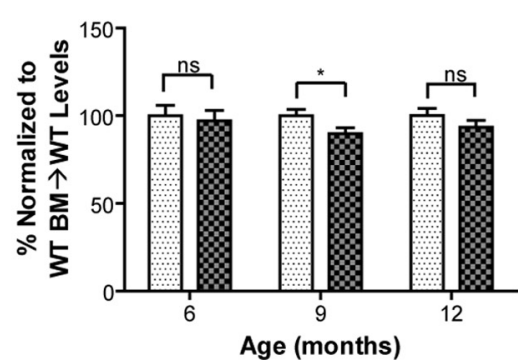

Figure 6. BMT ameliorates inflammatory cytokine and chemokine changes in YAC128 mice. At 6, 9, and 12 months, blood samples were isolated from experimental cohorts, and serum cytokines were determined using a mesoplex assay that measures multiple cytokines and chemokines. $\boldsymbol{A}, \boldsymbol{C}, \boldsymbol{E}, \boldsymbol{G}$, IL-6, CXCL1 (mouse homolog of IL-8), IFN- $\gamma$, and IL-10 were elevated in nontransplanted YAC128 mice relative to WT mice. Values are mean $\pm \mathrm{SEM}\left({ }^{*} p<0.05,{ }^{* *} p<0.01,{ }^{* * *} p<0.001, t\right.$ test $) . \boldsymbol{B}, \boldsymbol{D}, \boldsymbol{F}, \boldsymbol{H}$, These changes were not observed or were observed at reduced levels in chimeric $Y A C 128$ mice relative to chimeric WT mice. Values are mean $\pm \operatorname{SEM}\left({ }^{*} p<0.05,{ }^{* *} p<0.01, t\right.$ test $)$.

immune response and that chronic increases in chemokines might simply reflect an impairment of immune cells (such as leukocytes) in their ability to mount an effective innate immune response. Consistent with this scenario, we recently identified a profound impairment in the ability of monocytes isolated from HD patients to migrate toward the chemokine MCP-1, dramatic deficits in the migration of macrophages from HD mouse models to respond to a peritoneal thioglycollate challenge, and impaired process extension and retraction of microglial processes in BACHD mice as determined by two-photon in vivo imaging 
(Kwan W, Traeger U, Davalos D, Andre R, Chou A, Miller A, Möller T, Stella N, Akassaglou K, Tabrizi SJ, Muchowski PJ, unpublished observations). It is also important to emphasize that changes in peripheral levels of cytokines can also indirectly influence brain function and dysfunction by several different communication pathways from the periphery to the brain that include the humoral, neural, and cellular pathways (Capuron and Miller, 2011). For example, activation of endothelial cells in the brain parenchyma by cytokines, such as IL-6, is responsible for the subsequent release of second messengers that act on brain targets (Rothwell et al., 1996).

Two recent studies in mouse models provide additional support for the hypothesis that dysfunction of the peripheral immune system might play an important disease-modifying role in HD. Genetic deletion of the cannabinoid receptor $2\left(\mathrm{CB}_{2}\right)$, a protein expressed predominantly in peripheral immune cells that regulates production of proinflammatory cytokines likely via nuclear factor- $\kappa \mathrm{B}$ (Herring et al., 1998; Ehrhart et al., 2005; Mukhopadhyay et al., 2006), exacerbates pathogenesis in a mouse model of HD (Palazuelos et al., 2009). Consistent with these findings, we recently found that $\mathrm{CB}_{2}$ signaling in immune cells mediates the onset and severity of symptoms in BACHD mice and that $\mathrm{CB}_{2}$ agonists are neuroprotective in $\mathrm{R} 6 / 2$ mice, even when given at late disease stages (Larimore et al., unpublished observations). In an independent study, we found that peripheral inhibition of the mitochondrial enzyme kynurenine 3-monooxygenase (KMO) in blood cells increased survival and prevented synaptic loss and CNS inflammation in the R6/2 mouse model of HD (Zwilling et al., 2011). The neuroprotective effects of KMO inhibition are likely attributable at least in part to changes in neurotransmitter release that are controlled by the secretion of tryptophan metabolites from peripheral immune cells that cross the blood-brain barrier, but might also involve decreased cytokine production and suppression of innate immune responses in the periphery and CNS.

Chronic elevation of cytokines and chemokines could potentially have important clinical ramifications for HD patients. A recent study showed that acute and chronic systemic inflammation, associated with increases in serum TNF- $\alpha$, is associated with an increase in cognitive decline in $\mathrm{AD}$ (Holmes et al., 2009), and, based on our results, we would predict similar findings in HD patients. However, in contrast to $\mathrm{AD}$ patients, elevated levels of cytokines and chemokines in HD patients are found at the earliest disease stages and persist chronically throughout the entire disease course (Björkqvist et al., 2008). Thus, studies to examine the consequences of peripheral depletion of cytokines for which therapeutic monoclonal antibodies are widely used in humans, such as TNF- $\alpha$ and IL-6, in mouse models of HD are clearly warranted.

Finally, it is worth emphasizing that BMT is a widely used clinical procedure for numerous diseases, including sickle cell anemia, aplastic anemia, congenital neutropenia, leukemia, lymphoma, multiple myeloma, etc. Although this procedure involves well-characterized risks, it is generally well tolerated, and, in two independent HD mouse models, our studies showed no significant differences in their ability to tolerate lethal irradiation and $\mathrm{BMT}$ relative to littermate controls. As an alternative to BMT, mesenchymal stem cells, which can be derived from BM, may also hold promise for HD. Transplantation of mesenchymal cells engineered to overexpress brain-derived neurotrophic factor or nerve growth factor in the striata of YAC128 mice improved behavioral deficits (Dey et al., 2010). In a mouse model of cerebellar degeneration, transplantation with BM-derived mesenchymal cells resulted in increased transcripts of synaptic proteins and amelioration of electrophysiological deficits (Bae et al., 2007). Overall, these studies and the data presented in the current study support the continued investigation of potential diseasemodifying effects of immune cells in HD and may open up novel therapeutic strategies to treat this devastating disorder.

\section{References}

Ajami B, Bennett JL, Krieger C, Tetzlaff W, Rossi FM (2007) Local selfrenewal can sustain CNS microglia maintenance and function throughout adult life. Nat Neurosci 10:1538-1543.

Almeida S, Sarmento-Ribeiro AB, Januário C, Rego AC, Oliveira CR (2008) Evidence of apoptosis and mitochondrial abnormalities in peripheral blood cells of Huntington's disease patients. Biochem Biophys Res Commun 374:599-603.

Bae JS, Han HS, Youn DH, Carter JE, Modo M, Schuchman EH, Jin HK (2007) Bone marrow-derived mesenchymal stem cells promote neuronal networks with functional synaptic transmission after transplantation into mice with neurodegeneration. Stem Cells 25:1307-1316.

Beers DR, Henkel JS, Xiao Q, Zhao W, Wang J, Yen AA, Siklos L, McKercher SR, Appel SH (2006) Wild-type microglia extend survival in PU.1 knockout mice with familial amyotrophic lateral sclerosis. Proc Natl Acad Sci U S A 103:16021-16026.

Björkqvist M, Fex M, Renström E, Wierup N, Petersén A, Gil J, Bacos K, Popovic N, Li JY, Sundler F, Brundin P, Mulder H (2005) The R6/2 transgenic mouse model of Huntington's disease develops diabetes due to deficient beta-cell mass and exocytosis. Hum Mol Genet 14:565-574.

Björkqvist M, Wild EJ, Thiele J, Silvestroni A, Andre R, Lahiri N, Raibon E, Lee RV, Benn CL, Soulet D, Magnusson A, Woodman B, Landles C, Pouladi MA, Hayden MR, Khalili-Shirazi A, Lowdell MW, Brundin P, Bates GP, Leavitt BR, Möller T, Tabrizi SJ (2008) A novel pathogenic pathway of immune activation detectable before clinical onset in Huntington's disease. J Exp Med 205:1869-1877.

Byram SC, Carson MJ, DeBoy CA, Serpe CJ, Sanders VM, Jones KJ (2004) CD4-positive $\mathrm{T}$ cell-mediated neuroprotection requires dual compartment antigen presentation. J Neurosci 24:4333-4339.

Capuron L, Miller AH (2011) Immune system to brain signaling: neuropsychopharmacological implications. Pharmacol Ther 130:226-238.

Cardona AE, Huang D, Sasse ME, Ransohoff RM (2006) Isolation of murine microglial cells for RNA analysis or flow cytometry. Nat Protoc 1:19471951.

Cepeda C, Hurst RS, Calvert CR, Hernández-Echeagaray E, Nguyen OK, Jocoy E, Christian LJ, Ariano MA, Levine MS (2003) Transient and progressive electrophysiological alterations in the corticostriatal pathway in a mouse model of Huntington's disease. J Neurosci 23:961-969.

Dalrymple A, Wild EJ, Joubert R, Sathasivam K, Björkqvist M, Petersén A, Jackson GS, Isaacs JD, Kristiansen M, Bates GP, Leavitt BR, Keir G, Ward M, Tabrizi SJ (2007) Proteomic profiling of plasma in Huntington's disease reveals neuroinflammatory activation and biomarker candidates. J Proteome Res 6:2833-2840.

Davalos D, Grutzendler J, Yang G, Kim JV, Zuo Y, Jung S, Littman DR, Dustin ML, Gan WB (2005) ATP mediates rapid microglial response to local brain injury in vivo. Nat Neurosci 8:752-758.

Dey ND, Bombard MC, Roland BP, Davidson S, Lu M, Rossignol J, Sandstrom MI, Skeel RL, Lescaudron L, Dunbar GL (2010) Genetically engineered mesenchymal stem cells reduce behavioral deficits in the YAC 128 mouse model of Huntington's disease. Behav Brain Res 214:193-200.

Ding J, Cheng Y, Gao S, Chen J (2011) Effects of nerve growth factor and Noggin-modified bone marrow stromal cells on stroke in rats. J Neurosci Res 89:222-230.

Ehrhart J, Obregon D, Mori T, Hou H, Sun N, Bai Y, Klein T, Fernandez F, Tan J, Shytle RD (2005) Stimulation of cannabinoid receptor 2 (CB2) suppresses microglial activation. J Neuroinflammation 2:29.

Giorgini F, Möller T, Kwan W, Zwilling D, Wacker JL, Hong S, Tsai LC, Cheah CS, Schwarcz R, Guidetti P, Muchowski PJ (2008) Histone deacetylase inhibition modulates kynurenine pathway activation in yeast, microglia, and mice expressing a mutant huntingtin fragment. J Biol Chem 283:7390-7400.

Gray M, Shirasaki DI, Cepeda C, André VM, Wilburn B, Lu XH, Tao J, Yamazaki I, Li SH, Sun YE, Li XJ, Levine MS, Yang XW (2008) Fulllength human mutant huntingtin with a stable polyglutamine repeat can elicit progressive and selective neuropathogenesis in BACHD mice. J Neurosci 28:6182-6195. 
Hao W, Liu Y, Liu S, Walter S, Grimm MO, Kiliaan AJ, Penke B, Hartmann T, Rübe CE, Menger MD, Fassbender K (2011) Myeloid differentiation factor 88-deficient bone marrow cells improve Alzheimer's diseaserelated symptoms and pathology. Brain 134:278-292.

Heng MY, Tallaksen-Greene SJ, Detloff PJ, Albin RL (2007) Longitudinal evaluation of the $\mathrm{Hdh}(\mathrm{CAG}) 150$ knock-in murine model of Huntington's disease. J Neurosci 27:8989-8998.

Herring AC, Koh WS, Kaminski NE (1998) Inhibition of the cyclic AMP signaling cascade and nuclear factor binding to CRE and kappaB elements by cannabinol, a minimally CNS-active cannabinoid. Biochem Pharmacol 55:1013-1023.

Hirasawa T, Ohsawa K, Imai Y, Ondo Y, Akazawa C, Uchino S, Kohsaka S (2005) Visualization of microglia in living tissues using Iba1-EGFP transgenic mice. J Neurosci Res 81:357-362.

Hodgson JG, Agopyan N, Gutekunst CA, Leavitt BR, LePiane F, Singaraja R, Smith DJ, Bissada N, McCutcheon K, Nasir J, Jamot L, Li XJ, Stevens ME, Rosemond E, Roder JC, Phillips AG, Rubin EM, Hersch SM, Hayden MR (1999) A YAC mouse model for Huntington's disease with full-length mutant huntingtin, cytoplasmic toxicity, and selective striatal neurodegeneration. Neuron 23:181-192.

Holmes C, Cunningham C, Zotova E, Woolford J, Dean C, Kerr S, Culliford D, Perry VH (2009) Systemic inflammation and disease progression in Alzheimer disease. Neurology 73:768-774.

Hult S, Soylu R, Björklund T, Belgardt BF, Mauer J, Brüning JC, Kirik D, Petersén Å (2011) Mutant huntingtin causes metabolic imbalance by disruption of hypothalamic neurocircuits. Cell Metab 13:428-439.

Leblhuber F, Walli J, Jellinger K, Tilz GP, Widner B, Laccone F, Fuchs D (1998) Activated immune system in patients with Huntington's disease. Clin Chem Lab Med 36:747-750.

Menalled L, El-Khodor BF, Patry M, Suárez-Fariñas M, Orenstein SJ, Zahasky B, Leahy C, Wheeler V, Yang XW, MacDonald M, Morton AJ, Bates G, Leeds J, Park L, Howland D, Signer E, Tobin A, Brunner D (2009) Systematic behavioral evaluation of Huntington's disease transgenic and knock-in mouse models. Neurobiol Dis 35:319-336.

Mildner A, Schmidt H, Nitsche M, Merkler D, Hanisch UK, Mack M, Heikenwalder M, Brück W, Priller J, Prinz M (2007) Microglia in the adult brain arise from Ly-6ChiCCR2+ monocytes only under defined host conditions. Nat Neurosci 10:1544-1553.

Mukhopadhyay S, Das S, Williams EA, Moore D, Jones JD, Zahm DS, Ndengele MM, Lechner AJ, Howlett AC (2006) Lipopolysaccharide and cyclic AMP regulation of $\mathrm{CB}(2)$ cannabinoid receptor levels in rat brain and mouse RAW 264.7 macrophages. J Neuroimmunol 181:82-92.

Palazuelos J, Aguado T, Pazos MR, Julien B, Carrasco C, Resel E, Sagredo O, Benito C, Romero J, Azcoitia I, Fernández-Ruiz J, Guzmán M, GalveRoperh I (2009) Microglial CB2 cannabinoid receptors are neuroprotective in Huntington's disease excitotoxicity. Brain 132:3152-3164.

Politis M, Pavese N, Tai YF, Kiferle L, Mason SL, Brooks DJ, Tabrizi SJ, Barker RA, Piccini P (2011) Microglial activation in regions related to cognitive function predicts disease onset in Huntington's disease: a multimodal imaging study. Hum Brain Mapp 32:258-270.

Propert DN (1980) Presymptomatic detection of Huntington's disease. Med J Aust 1:609-612.

Ransohoff RM (2007) Microgliosis: the questions shape the answers. Nat Neurosci 10:1507-1509.

Rosas HD, Koroshetz WJ, Chen YI, Skeuse C, Vangel M, Cudkowicz ME, Caplan K, Marek K, Seidman LJ, Makris N, Jenkins BG, Goldstein JM (2003) Evidence for more widespread cerebral pathology in early HD: an MRI-based morphometric analysis. Neurology 60:1615-1620.

Rothwell NJ, Luheshi G, Toulmond S (1996) Cytokines and their receptors in the central nervous system: physiology, pharmacology, and pathology. Pharmacol Ther 69:85-95.
Runne H, Kuhn A, Wild EJ, Pratyaksha W, Kristiansen M, Isaacs JD, Régulier E, Delorenzi M, Tabrizi SJ, Luthi-Carter R (2007) Analysis of potential transcriptomic biomarkers for Huntington's disease in peripheral blood. Proc Natl Acad Sci U S A 104:14424-14429.

Sapp E, Kegel KB, Aronin N, Hashikawa T, Uchiyama Y, Tohyama K, Bhide PG, Vonsattel JP, DiFiglia M (2001) Early and progressive accumulation of reactive microglia in the Huntington disease brain. J Neuropathol Exp Neurol 60:161-172.

Sassone J, Colciago C, Cislaghi G, Silani V, Ciammola A (2009) Huntington's disease: the current state of research with peripheral tissues. Exp Neurol 219:385-397.

Sathasivam K, Hobbs C, Turmaine M, Mangiarini L, Mahal A, Bertaux F, Wanker EE, Doherty P, Davies SW, Bates GP (1999) Formation of polyglutamine inclusions in non-CNS tissue. Hum Mol Genet 8:813-822.

Simard AR, Soulet D, Gowing G, Julien JP, Rivest S (2006) Bone marrowderived microglia play a critical role in restricting senile plaque formation in Alzheimer's disease. Neuron 49:489-502.

Simmons DA, Casale M, Alcon B, Pham N, Narayan N, Lynch G (2007) Ferritin accumulation in dystrophic microglia is an early event in the development of Huntington's disease. Glia 55:1074-1084.

Slow EJ, van Raamsdonk J, Rogers D, Coleman SH, Graham RK, Deng Y, Oh R, Bissada N, Hossain SM, Yang YZ, Li XJ, Simpson EM, Gutekunst CA, Leavitt BR, Hayden MR (2003) Selective striatal neuronal loss in a YAC128 mouse model of Huntington disease. Hum Mol Genet 12:1555-1567.

Soulet D, Cicchetti F (2011) The role of immunity in Huntington's disease. Mol Psychiatry 16:889-902.

Stoy N, Mackay GM, Forrest CM, Christofides J, Egerton M, Stone TW, Darlington LG (2005) Tryptophan metabolism and oxidative stress in patients with Huntington's disease. J Neurochem 93:611-623.

Tabrizi SJ, Scahill RI, Durr A, Roos RA, Leavitt BR, Jones R, Landwehrmeyer GB, Fox NC, Johnson H, Hicks SL, Kennard C, Craufurd D, Frost C, Langbehn DR, Reilmann R, Stout JC; TRACK-HD Investigators (2011) Biological and clinical changes in premanifest and early stage Huntington's disease in the TRACK-HD study: the 12-month longitudinal analysis. Lancet Neurol 10:31-42.

Tai YF, Pavese N, Gerhard A, Tabrizi SJ, Barker RA, Brooks DJ, Piccini P (2007) Microglial activation in presymptomatic Huntington's disease gene carriers. Brain 130:1759-1766.

van der Burg JM, Björkqvist M, Brundin P (2009) Beyond the brain: widespread pathology in Huntington's disease. Lancet Neurol 8:765-774.

Wacker JL, Huang SY, Steele AD, Aron R, Lotz GP, Nguyen Q, Giorgini F, Roberson ED, Lindquist S, Masliah E, Muchowski PJ (2009) Loss of Hsp70 exacerbates pathogenesis but not levels of fibrillar aggregates in a mouse model of Huntington's disease. J Neurosci 29:9104-9114.

Wake H, Moorhouse AJ, Jinno S, Kohsaka S, Nabekura J (2009) Resting microglia directly monitor the functional state of synapses in vivo and determine the fate of ischemic terminals. J Neurosci 29:3974-3980.

Wild E, Magnusson A, Lahiri N, Krus U, Orth M, Tabrizi SJ, Björkqvist M. (2011) Abnormal peripheral chemokine profile in Huntington's disease. PLoS Curr 3:RRN1231.

Zhang C, Li Y, Chen J, Gao Q, Zacharek A, Kapke A, Chopp M (2006) Bone marrow stromal cells upregulate expression of bone morphogenetic proteins 2 and 4, gap junction protein connexin-43 and synaptophysin after stroke in rats. Neuroscience 141:687-695.

Zwilling D, Huang SY, Sathyasaikumar KV, Notarangelo FM, Guidetti P, Wu HQ, Lee J, Truong J, Andrews-Zwilling Y, Hsieh EW, Louie JY, Wu T, Scearce-Levie K, Patrick C, Adame A, Giorgini F, Moussaoui S, Laue G, Rassoulpour A, Flik G, Huang Y, Muchowski JM, Masliah E, Schwarcz R, Muchowski PJ (2011) Kynurenine 3-monooxygenase inhibition in blood ameliorates neurodegeneration. Cell 145:863-874. 